\title{
Cash Flow in an Agribusiness Restructuring Process
}

\author{
Rubens Corrêa Junior (Corresponding author) \\ Department of Biosystems Engineering, University of São Paulo \\ 255, Duque de Caxias Avenue, CEP 13635-900, Pirassununga, São Paulo, Brazil \\ Tel: +55 19 3565-4224 Email: correarubens_6@hotmail.com \\ Augusto Hauber Gameiro \\ Department of Animal Science, University of São Paulo \\ 255, Duque de Caxias Avenue, CEP 13635-900, Pirassununga, São Paulo, Brazil \\ Tel: +55 19 3565-4224 Email: gameiro@usp.br
}

Received: Sep. 29, $2020 \quad$ Accepted: Oct. 18, $2020 \quad$ Published: Oct. 19, 2020

doi:10.5296/jas.v8i4.17850

URL: https://doi.org/10.5296/jas.v8i4.17850

\begin{abstract}
The purpose of this article is to present cash flow as an accessible and efficient tool for the management of small and medium-sized egg companies, including those close to bankruptcy, aiming at their financial recovery. In order to achieve results, action research and the cash flow management method were adopted. The data were collected from a Brazilian egg producer that was close to bankruptcy. Data collection, implementation of the management tool and performance monitoring took place between July 2016 and December 2017. The use of the cash flow tool allowed the company's financial recovery, which led to an increase of 951.5\% in its cash and cash equivalents at the end of the research period, generating $22.5 \%$ of cash on the operating result and maintaining its minimum balance of cash by $23.6 \%$ above the limit required for it to keep operating safely. The method considered only the Cash Flow Statement, as it is the most practical and easy to understand for managers who have no management experience or training. The Balance Sheet and Income Statement were not explored. From the research results it is expected that the proposed management tool would be adopted by other small and medium-sized egg producers in Brazil, as well as in other branches of agribusiness. Hitherto, we are not aware of the availability of a tool proposed for small and medium companies in the animal production segment in Brazil. Therefore, it could be a valuable contribution to the socioeconomic development of this sector.
\end{abstract}

Keywords: cash flow, agricultural finance, restructuring, small business 


\section{Introduction}

Small and medium-sized companies are considered an integral part of the economy, because they have relevant participation in the development of a country (Bielikova \& Mazanec, 2016). With some characteristics that differ from large companies, small and medium-sized companies in Brazil have a significant mortality rate. According to the Brazilian Service of Business Support for Micro and Small Companies (Sebrae, 2016) and the Statistics and Geography Brazilian Institute (IBGE, 2017a), companies incorporated in 2010 had a mortality rate of $44.4 \%$ and had their activities closed in the first two years. When considering the first five years of operation from that same year, the mortality rate rises to $62.2 \%$. Among several causes for this result, the main one is a lack of rigour in the control of cash flow.

Cash flow management provides the manager with the necessary financial information to signal a possible need for cash in advance, to prevent the company from running out of resources to support its operation. The benefit of this information is significant for small and medium-sized companies, because when compared to large companies, the cost of raising the money needed is higher and the availability of credit is more restricted (Gitman, 1997; Tauringana \& Afrifa, 2013). Understanding financial statements to make decisions is a challenging task for managers of small and medium-sized enterprises (Maingot \& Zeghal, 2006). When analysing small and medium agricultural producers, the challenge is even greater, as most have family management with little training and business knowledge (IBGE, 2017b). However, small and medium-sized rural producers are companies that also demand good management of their property, not only as a family asset, but as a business that generates good results.

The evolution of agribusiness in Brazil, as a sector of the economy that drives the growth of the Gross Domestic Product, places the country among the ten largest in the world, being the fourth largest agricultural producer, the third largest producer of chicken and the seventh largest in egg production (Food and Agriculture Organization of the United Nations - FAO, 2016). Among the largest producers, the commercial eggs segment in the country has great relevance for economic development. There are 163.7 million birds in egg production, producing 728 million dozen eggs per year and generating $\mathrm{R} \$ 10.4$ billion for the domestic economy (IBGE, 2018). However, the challenges for producers are great in relation to the price instability of agricultural products, as well as the biological and climatic variables involved in production. Therefore, the cash flow management of a rural producer needs to be very well aligned and prepared to face the uncontrollable variables that the activity is susceptible to. According to Araújo and Marion (1997), the concern of producers has ceased to be the domain of production techniques and has become the acquisition of skills to make financial decisions that can keep their production at the lowest cost and best margin of profitability.

The development of this research is justified by the fact that small and medium rural producers in Brazil have a tendency to make strategic decisions based on intuition to achieve a future result and are unable to predict, with the necessary precision, the continuity of their 
businesses both in short and medium terms. The difficulty in coordinating management activities with daily routines and the lack of financial controls are other important points that become bottlenecks to the good financial performance of these companies. The absence of planning focused on financial performance leads managers to administer their companies in a non-professional, informal way and with a shortage of financial resources (Leone, 1999).

Using the action research method, based on a real case of a commercial farm with strong financial difficulties, having as a main activity the production of eggs and as a secondary activity the production of pig, this work aims to evaluate whether with the use of a cash flow tool it is possible for rural producers to manage their business and make the necessary decisions to obtain the expected results.

\section{Review of Relevant Literature}

\subsection{Cash Flow for Management}

Among several definitions, cash flow can be understood as the 'backbone' of an organisation because it demonstrates the information or resources necessary to sustain operations and the period in which there will be a real need to raise funds for the continuity of the operation (Gitman, 1997). Cash flow management in small and medium-sized companies is essential to ensure financial performance and control over cash availability. The benefit of good cash flow management is significant, as small and medium-sized companies, when compared to larger companies, have higher funding costs when they need money (Tauringana \& Afrifa, 2013).

Ross et al. (1998) state that cash flow can be considered as set of the most important information extracted from financial statements. It is through this that the financial manager gets to know the amount of money received and the amount of money that left the company. In addition to being a tool used to assess the value of the company over time, the cash flow decision process demonstrates a greater emphasis on what is of interest and concern to the entrepreneur; the cash value available for investments and working capital (Das, 2017).

It is important to highlight that the use of cash flow contributes to financial reorganisation and new strategies related to growth, survival and competitiveness. When a company faces financial difficulties, it is possible to realise, with cash flow management, that the amount of cash and cash equivalents is not enough to cover the contracted payments and thus signal a serious problem to the manager (Ross et al., 2002). Therefore, monitoring cash flow as a management tool for small and medium-sized companies helps avoid financial difficulties, insolvency proceedings, liquidation of assets for debt payments, borrowing at high interest rates, investments in unprofitable projects, loss of operational efficiency and bankruptcy (Yahya et al., 2016).

\subsection{Cash Flow Planning}

According to Haskins et al. (1987), financial planning requires that small, medium and large companies have the ability to understand the cash inflows and outflows of cash flows with future needs in order to position the company between success and failure. In order to plan 
for future needs, the financial manager reflects their analysis on the results of events that have already occurred so that they can guide their future projections, also taking the opportunity to correct mistakes made in the past (Cheatham \& Cheatham, 1993).

Cash planning can be prepared for any period and it is recommended that the projected period be divided into monthly intervals for companies that have seasonal and uncertain flows. Companies with more stable cash flows can project their financial results at quarterly, half-yearly or annual intervals (Gitman, 1997). Planning something that has not yet taken place requires care with respect to risks and uncertainties. Risks and uncertainties are interrelated, but differ as, in terms of planning, risks can be measurable whereas uncertainties cannot (Knight, 1964). Therefore, Ross et al. (2002) recommend that the planning process is prepared in three alternative scenarios in order to reduce risks and uncertainties: 1) pessimist: the financial manager in this plan foresees the worst projections and risks that the company may experience during the period, considering the liquidation of assets for payment of debts and the closure of activities; 2) more probable: planning in this scenario will consider the most likely projections in relation to the company and the economic scenario, presenting a greater balance between favourable and unfavourable projections; 3 ) optimist: in this scenario, the company traces its projection based on the most optimistic hypotheses, providing for expansion of operations, launch of new products, sales with accelerated growth, among others.

Using a cash flow planning tool is the best way for small and medium-sized farmers to deal with cash problems before they occur, avoiding surprises and poor decisions. Therefore, when a producer does not financially predict what will happen to their business, there is a high risk of mismanagement. The manager may mistake, for instance, incoming cash receipts in a period when sales decreased for receipts referring to previous periods when sales were high, and they may fail to recognise an urgent need for intervention of resources to keep property obligations up to date (Cheatham \& Cheatham, 1993).

\subsection{Operating Cycle and Cash Management}

According to a study by Pais and Gama (2015) with a group of small and medium-sized Portuguese companies, efficient working capital management has become vital for business performance. Their results indicated that a reduction in the level of inventories maintained and the number of days it takes companies to pay suppliers and receive from customers are associated with greater financial profitability.

Rural producers can have an optimum level of working capital that allows them to work with a liquidity margin and maximise their equity value. However, some events lead the producer to make decisions that may require a much greater amount of investment in working capital than the company needs (Deloof, 2003). However, working capital is generated by a lack of synchronisation between the company's receipt and payment dates, which can be positive when receipts are greater than payments or negative when payments are greater than receipts (Assaf Neto \& Silva, 2012).

To guarantee operating activities in the short term, efficient cash management is measured 
through the operating cycle and the cash cycle. The operating cycle is comprised of the period in which the company acquires the raw material, produces, stores, sells and receives from its customers. The operating cycle for a poultry producer can be determined by the following calculation (Gitman, 1997; Assaf Neto \& Silva, 2012):

$$
\text { Operational cycle }=A R M+A P T+A S T+A R T
$$

where:

$\mathrm{ARM}=$ average storage time for raw materials

$\mathrm{APT}=$ average production time

$\mathrm{AST}=$ average sales term

$\mathrm{ART}=$ average receivables term

The cash cycle, also known as the financial cycle, comprises the period between the payment of input suppliers (raw materials and labour) and the receipt of sales for goods produced. The calculation of the cash cycle is obtained by the formula (Gitman, 1997; Ross et al., 2002):

$$
\text { Cash cycle }=\text { Operational cycle }- \text { ASP }
$$

where:

$\mathrm{ASP}=$ average supplier payment term

When the company has a positive cash cycle, the financial manager will need to use loans to finance the cash cycle. In this case, by investing in working capital and forming the amount necessary to support this period, the company avoids resorting to loans with high interest costs (Gitman, 1997; Pais \& Gama, 2015). The ideal condition for any company would be that the average payment terms are longer than the operating cycle, thus eliminating investment in working capital or borrowing. In this situation, the company can benefit from using these sources of funds to support other business needs for better performance, in addition to the operational cycle (Gitman, 1997). Therefore, Gitman (1997) reinforces that the financial manager must aim at strategies that minimise the number of days necessary to finance the cash cycle without jeopardising sales and summarises these strategies in three points: 1) renew inventories as quickly as possible in order to avoid running out of inventories and hampering company sales; 2) shorten the deadline for receiving sales without motivating falls in sales volume and exaggerated pressure on customers. Financial discounts during sales, as long as they are economically viable, can be used to achieve this goal, and 3) extend the term of payment of accounts payable as much as possible, without harming the company's credit with the supplier, and always negotiate favourable discounts.

\subsection{Importance of the Minimum Cash Balance}

Uncertainty can lead to situations in which the company sometimes has more expenses than planned. Therefore, companies with greater cash uncertainty should retain more cash (Opler 
et al., 1999). Keynes (1982) describes three reasons that guide the entrepreneur to run a company with a minimum cash balance. The first reason is related to the business. The company needs to have liquid resources to ensure the interval between the payment of expenses and the receipt of sales due to the lack of synchrony present in the cash flow. The second reason is related to precaution. Owing to the risks and uncertainties present in the execution of financial planning, the company must be cautious in relation to unexpected events that may arise during the operational activities and surprise the manager if they do not have a minimum cash balance. As a last reason, the author recommends the company have a reservation to guarantee opportunities that occasionally present themselves with advantageous conditions.

The calculation of the minimum cash balance for small and medium entrepreneurs can be complex when adopting mathematical models that involve statistical knowledge. Assaf Neto and Silva (2012) define a simple way to establish the minimum amount of money that a company should keep in cash, as shown in the formula:

$$
\text { Minimum Cash Balance }=\frac{\text { Total cash disbursements }}{\text { Cash turnover }}
$$

where,

Cash turnover $=\frac{360 \text { days }}{\text { Cash cyole }}$

Thus, as the minimum cash balance is obtained by dividing the total payments by the cash flow, the greater the turnover, the lower the minimum cash balance will be and thus the manager can seek the efficiency of the cash flow by reducing the average terms that make up the cash cycle. Therefore, due to the simplicity of the calculation, the result obtained must be adopted with caution by the financial manager who must also assess whether the results are close to the reality of the company's business or not (Assaf Neto \& Silva, 2012).

\subsection{Data}

The database was collected from a small farm producing eggs for commercial laying and pigs for slaughter, located in the Pirassununga region, in the State of São Paulo, Brazil, with annual sales of around $\mathrm{R} \$ 6.0$ million and family management. A variety of tools and techniques for gathering information about the researched company were used for this work, such as: a) semi-structured interviews with directors and owners; b) meetings with the directors and employees of the company; c) informal conversations; d) observation of researchers; and e) collection of documentary information. The research took place between the months of July 2016 and December 2017, as shown in Figure 1. 


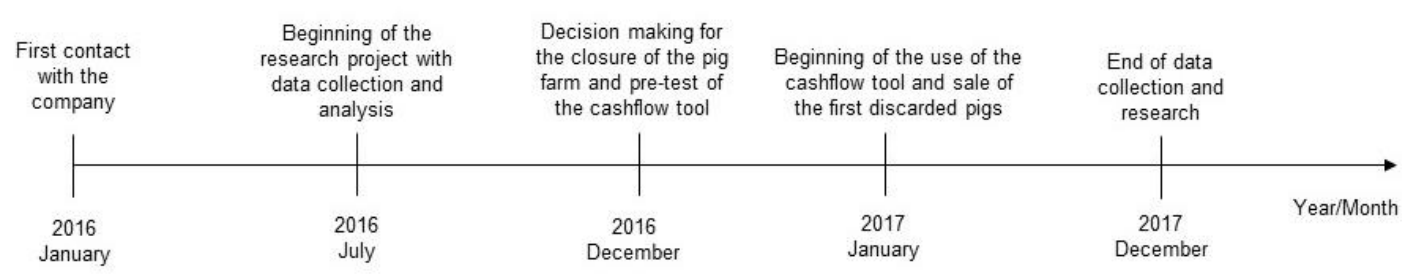

Figure 1. Research timeline

\section{Methodology}

\subsection{Action Research}

As an outline for this work, the action research technique was adopted, which Kemmis and McTaggart (1988) define as:

Action research is a form of collective, self-reflective inquiry that participants in social situations undertake to improve: (1) the rationality and justice of their own social or educational practices; (2) the participants' understanding of these practices and the situations in which they carry out these practices. Groups of participants can be teachers, students, parents, workplace colleagues, social activists or any other community members - that is, any group with a shared concern and the motivation and will to address their shared concern. The approach is action research only when it is collaborative and achieved through the critically examined action of individual group members. (p.5)

French (2009) describes action research as an appropriate methodological tool for research related to management and organisation in the business field. Coghlan and Brannick (2001), and Moss et al. (2007) reinforce that action research can be based on a collaborative relationship to solve a problem between researchers and a client, aiming not only at solving the problem, but also at generating new knowledge. Therefore, the choice of the action research method for this work was motivated by two situations: (1) the involvement of researchers in a financial restructuring project as a professional activity; (2) the interest in deepening the scientific knowledge of cash flow modelling for decision-making in small and medium rural companies. To apply the action research methodology, Coughlan and Coghlan (2002) propose that a cyclical process be performed as illustrated in Figure 2 and described below. 


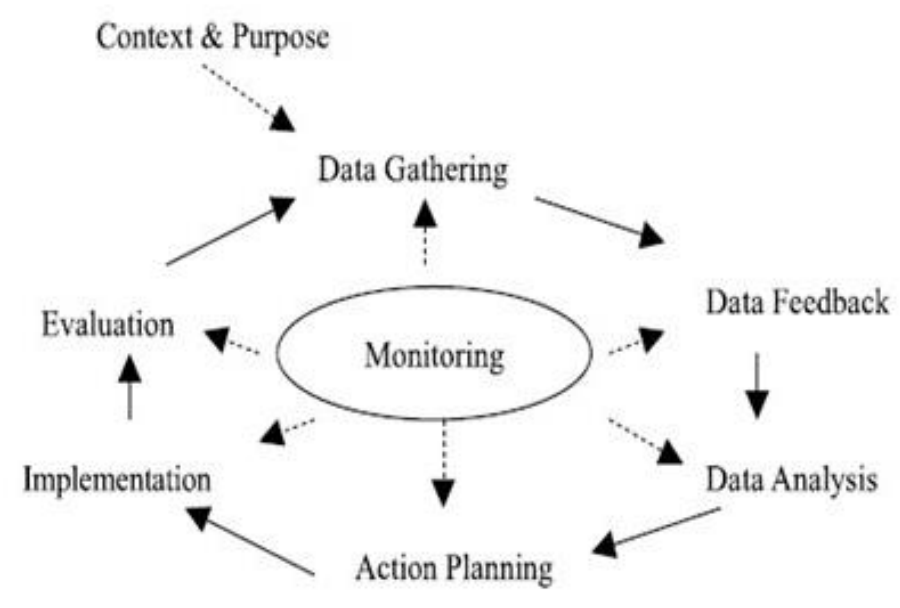

Figure 2. Action research cycle

Source: Coughlan, P. and Coghlan, D. (2002), “Action research for operations management”, International Journal of Operations \& Production Management, Vol. 22 No. 2, pp. 220-240.

\section{(1) Context \& Purpose}

This initial stage of action research aims at connecting researchers to the context and proposal of the action project. The first meeting held with the directors at the company, the object of study, was structured as an interview with two questions: (1) 'What were the reasons that led the company to seek external support for management?' and (2) 'What are the main decisions made that contributed to the current scenario?' In order to better understand the context of the company in the view of the collaborators, the researchers also met with the administrative and production teams, to collect information about the company from different sources. The meeting with the collaborators was divided into two parts: the first part had the presence of the directors for the presentation of the project proposal and the researchers as team members, and the second part only with the collaborators and the researchers, in order not to inhibit them with the presence of the directors and not to cause bias in the collection of information about the company from the point of view of employees.

\section{(2) Data Gathering}

This stage was considered the main stage for researchers. Based on the interviews and initial meetings that took place in step 1, the survey started to gather the first information and data from the company. Much of the information was collected through observation of the researchers during their experience in the company's day-to-day life, because by carrying out a prior assessment of the documents made available by the company, a significant amount of incomplete information was found due to lack of controls.

(3) Data Feedback

After the data collection period described in the previous step, an analysis was carried out on 
the quality of the information collected, as well as its importance for the development of improvement actions. The evaluation of the data was sufficient to carry out the analysis and planning of the actions.

(4) Data Analysis

Based on the data collected in the interviews, meetings, documents and observation of the researchers, information was organised into four major areas of the company: finance, human resources, sales and production. The technique chosen for the analysis of the collected data was content analysis, validating the information through the triangulation of different sources of data information. According to Mozzato and Grzybovski (2011), “[...] content analysis aims to overcome uncertainties and enrich the reading of the collected data" (p.734).

\section{(5) Action Planning}

This step addressed the preparation of the action plan with the main measures that should be taken to improve the financial results of the business. The actions were formulated with the observation of the researchers and their professional experience, information from the directors and employees and documents. Since each company has its peculiarities, even being in the same industry, the characteristics analysed, as well as the type of research, the management model, the company's culture, among other factors make the action plan unique and exclusive for the company, the object of study. The action plan deliberated organising company information by area, that is, improvement actions were proposed for the areas of finance, human resources, commercial and production. The finance area was the basis for planning, since it is related to the objective of this work, and the other areas had their actions implemented in sequence.

(6) Implementation

During the implementation phase, the employees responsible for the action met weekly in meetings called committees, to present to the researchers the evolution of the actions and difficulties faced in their implementation. In almost all the committees, one of the directors was present. The changes and revisions to the action plan, when necessary, were carried out by the researchers.

\section{(7) Evaluation}

The evaluation process after the implementation of the actions aims to assess whether they had achieved the expected result. This phase proposes the generation of knowledge and learning to the researchers and the people involved. If there is an action implemented without success, the action research cycle is repeated from the review of planning and actions so that the cycle is completed. Without the action evaluation step, regardless of success or failure, action research can become ineffective.

(8) Monitoring

Monitoring, as a goal step, occurs at all stages of action research. It aims to monitor, continuously and in real time, how the steps are being conducted, to avoid problems that may 
hinder the end of the action research cycle. Monitoring was carried out by the researchers themselves, providing control over the development of the research, knowledge of the processes and collection of new information.

\subsection{Cash Flow as a Tool}

The Cash Flow Statement (CFS), proposed by the Financial Accounting Standards Board (1987), was adopted as the main financial tool for the development of this research. The choice of this model was due to its practicality in operationalising the company's day-to-day activities and providing an analysis of the three strategic visions: operational, investment and financing. The CFS can be obtained by two methods: direct and indirect. For this work, the direct method was used, which allows obtaining information from the daily cash flow entries, being simpler and easier for the user in comparison to the indirect method that requires technical knowledge in the accounting area.

Five financial indicators were defined for monthly monitoring. With the same objectivity as cash flow, simplicity was sought in the indicators, to facilitate the understanding of the producer and their importance for the business. The first indicator was called 'Are we profitable?' and measured the company's ability to convert its sales into cash. The second indicator was called 'How much do we use to reinvest?' and it showed how much the company was using its operating results for new investments in the operation. The third indicator was called 'How much do we use to pay debts?' and measured the ability to pay debts with suppliers, banks and others based on the result of the operational flow. The fourth indicator was called 'What is our cash generation (balance increase)?' and it measured the company's performance in generating cash in relation to revenues to be invested in working capital and new investments in the future. Finally, the fifth indicator was called 'Minimum cash balance', which showed how much the company had available in relation to the minimum balance dimensioned for the operation.

The monetary values of this work are expressed in Brazilian reais. The fee for converting to US dollars mentioned in the note was extracted from the Brazilian Central Bank site, using the average quotation for the project period as a basis. ${ }^{1}$

\section{Results}

\subsection{Before Cash Flow Implementation}

The company did not have a cash flow to control money inflows and outflows that happened every day. Thus, the owner/manager did not have secure and organised information to support him in his decision-making, nor did he have data that signalled the main operations of the company to give him the certainty that the final balance values, when added together, checked exactly in cents of reais with the balances of bank and cash accounts. In addition to the lack of a cash flow management tool, the company faced intense financial difficulties due to the lack of working capital, which in a few months could cause the business to fail.

From 2006, the company began to face financial difficulties, which were seen by the owner/manager, according to his experience, as something controllable and manageable. 
However, the market was changing, and new competitors arrived in egg production. The financial difficulties started to worsen after 2006 as the production structure required maintenance and also because of the need for new investments in the renovation of the pig and poultry stock. In 2016, the company had 40 employees and no capital to keep the operation running. Owing to poor management, employees' salaries were delayed. In addition to this, the prices of corn and soybean meal, the main inputs for animal feed, were high, which further increased the imminent risk of bankruptcy.

The company no longer had egg production according to its productive capacity, because, due to financial difficulties, the producer had stopped the poultry rearing and the breeding stock was reduced from 120000 birds to 60000 birds. Pig production operated until the nursery stage, when the animals reached 22 kilos and were sold to another producer, who continued the growth and finishing process until the pigs reached the weight of 100 kilos and were ready for slaughter. The growth and termination facilities were stopped because of lack of capital. The animals sold were paid for in exchange for bulk corn, due to the producer's credit restriction with input suppliers. Owing to all this difficulty, the biggest challenge for the owner/manager was to keep the animals fed, because in the last months this has not been happening every day. For him, the decisions to keep the company expanding were not planned according to the cash conditions, and the capital that the company had was not managed correctly, a fact which comes as an answer to the second question about the main decisions made that contributed to the current scenario. Thus, for both him and his wife, a promising and reversible scenario would come with the resumption of the growth and termination stages of piglets, as selling them at the slaughter weight would bring greater profitability than selling them at the nursery stage.

Using the technique of data collection by observation and information gathering with employees and directors, a diagnostic map was drawn up with the main problems of the company, as shown in Table I.

Table I. Diagnostic map of the company's main problems

\begin{tabular}{|c|c|c|}
\hline PROBLEMS & SITUATIONS & REASONS \\
\hline \multirow{6}{*}{ EGG PRODUCTION } & Reduction from 120000 birds to 60000 birds & Financial resources \\
\hline & Frequent lack of feed for birds & Financial resources \\
\hline & Poultry with low productivity and average age of 120 weeks & Financial resources \\
\hline & Management problems & Human resources \\
\hline & High index of eggs with thin shell and cracked & Financial resources \\
\hline & Lack of inputs for product packaging & Financial resources \\
\hline \multirow{5}{*}{ PIG PRODUCTION } & Management problems & Human resources \\
\hline & High mortality rate & Human resources \\
\hline & Use of low genetic matrix to recompose the farm & Financial resources \\
\hline & Facilities and equipment in poor condition & Financial resources \\
\hline & Frequent lack of ingredients for animal feed & Financial resources \\
\hline \multirow{4}{*}{ HUMAN RESOURCES } & High turnover and absenteeism & Financial resources \\
\hline & Payroll and other overdue benefits & Financial resources \\
\hline & Workforce without training & Financial resources \\
\hline & Low motivation of the whole team & Financial resources \\
\hline \multirow{2}{*}{ COMMERCIAL } & Customers migrating to the competition & Quality resources \\
\hline & High rate of exchange and return of goods & Quality resources \\
\hline
\end{tabular}


FINANCIAL

\begin{tabular}{|l|c|}
\hline Fragile commercial service & Human resources \\
\hline Low-quality internal control ERP & Financial resources \\
\hline Absence of financial and cash flow controls & Human Resources \\
\hline Deficiency in the performance of routine activities & Human Resources \\
\hline
\end{tabular}

According to the information shown in Table I, a financial analysis of the viability of the company's two operating units (egg production and pig production) was carried out. Due to the tradition in egg production, this business unit was the one that generated the most revenue for the company. With a share of about $73.0 \%$ in total revenues, egg production, even though inefficient, mainly because of quality issues as well as the breeding stock age, guaranteed the company's revenue with the conquered market. Within a radius of up to $100 \mathrm{~km}$ from the company's headquarters, the brand of eggs was still known and remembered for its period of success in the early 2000s. However, its success did not guarantee sales to major supermarket chains. Because of a lack of quality both relating to the eggs and to the service provided, large supermarket chains had started buying eggs from other sellers. With the loss of large customers, the company began to focus its commercial strength on small door-to-door retailers, small supermarkets, restaurants, grocery stores and bakeries that did not demand as much quality as large retailers. Therefore, the egg operation required an increase in capital for renewal of the breeding stock, purchase of inputs and training of labour, as this would make it possible to guarantee the quality of the product on the market and re-establish the company's financial results in the short term.

The pig operation accounted for about $27.0 \%$ of the company's total revenues and sales were concentrated on two small pig producers who bought the animals for fattening and meat processing. The researchers followed employee activities in the pig sector for several days to collect information. Productivity was very low because of several factors, among them, the lack of mastery of technical management knowledge, inadequate facilities and gilt breeding stock. These factors contributed to the high mortality rate of newborns.

When modelling a cash flow with historical expenses together with the board, the pig operation pointed to a deficit result. The monthly cost to maintain the farm was R\$ 166689.63 for 1300 animals housed with expenses related to feed, labour and other materials (medicines, vaccines, insemination and others), as shown in Table II. The average revenue from the operation was around $\mathrm{R} \$ 120000.00$ per month. Thus, the monthly result was a deficit of around $\mathrm{R} \$ 47000.00$, corresponding to an accumulated amount of $\mathrm{R} \$ 564000.00$ per year.

Table II. Monthly cost of pig production

\begin{tabular}{l|c|r|r|r|r}
\hline \multicolumn{1}{c|}{ CYCLE } & $\begin{array}{c}\text { NUMBER OF } \\
\text { ANIMALS }\end{array}$ & \multicolumn{1}{c|}{ FEED } & \multicolumn{1}{c|}{ PAYROLL } & \multicolumn{1}{c}{$\begin{array}{l}\text { OTHER } \\
\text { COSTS }\end{array}$} & \multicolumn{1}{c}{ TOTAL } \\
\hline Gestation & 265 & $\mathrm{R} \$ 22322.33$ & $\mathrm{R} \$ 6000.00$ & $\mathrm{R} \$ 2493.75$ & $\mathrm{R} \$ 30816.08$ \\
\hline Farrowing & 35 & $\mathrm{R} \$ 7534.80$ & $\mathrm{R} \$ 3000.00$ & $\mathrm{R} \$ 218.75$ & $\mathrm{R} \$ 10753.55$ \\
\hline Nursery & 400 & $\mathrm{R} \$ 18630.00$ & $\mathrm{R} \$ 3000.00$ & $\mathrm{R} \$ 1400.00$ & $\mathrm{R} \$ 23030.00$ \\
\hline Finisher & 600 & $\mathrm{R} \$ 97290.00$ & $\mathrm{R} \$ 3000.00$ & $\mathrm{R} \$ 1800.00$ & $\mathrm{R} \$ 102090.00$ \\
\hline TOTAL & $\mathbf{1 . 3 0 0}$ & $\mathbf{R} \$ \mathbf{1 4 5 7 7 7 . 1 3}$ & $\mathbf{R} \$ \mathbf{1 5 0 0 0 . 0 0}$ & $\mathbf{R} \$ \mathbf{5 9 1 2 . 5 0}$ & $\mathbf{R} \$ \mathbf{1 6 6} \mathbf{6 8 9 . 6 3}$ \\
\hline
\end{tabular}




\section{$\triangle$ Macrothink}

Based on these data, it was possible to verify that the egg operation also had a deficit of $\mathrm{R} \$ 900000.00$ per year. The revenue generated of around $\mathrm{R} \$ 240000.00$ per month from the sale of eggs and manure was not sufficient to cover expenses which added up to approximately $\mathrm{R} \$ 365000.00$. The low productivity of the birds, between $60 \%$ and $65 \%$, and the cost of feed inputs were the main factors responsible for this negative difference in the financial result. Corn, the main feed input, was being purchased at a price of $\mathrm{R} \$ 52.00 / \mathrm{bag}$, while the average market price was R $\$ 45.00 /$ bag. Nonetheless, due to his credit restriction, the producer was willing to pay $15.5 \%$ more to have the product. This was also true for other kinds of input.

Analysing the company's two operations, both showed deficit results. However, the two business units would require investments in working capital and in replenishing the stock to remain viable. Continuing with the two operations or focusing on only one were the options for decision-making that the company needed at that time.

The SWOT matrix method was used to analyse the two options and identify the best of them. This method allows analysing an organisation and its environments based on strengths (S) and weaknesses (W) as the company's internal factors, and opportunities (O) and threats (T) as external factors that can influence business strategies. The matrix encourages managers to analyse a company's situation to develop strategies, tactics and actions that will make organisational objectives effective and efficient (Weihrich, 1982). Therefore, with the SWOT analysis it was possible to understand the strengths, weaknesses, opportunities and threats of the company in the operations of eggs and pig, as shown in Figures 3 and 4.
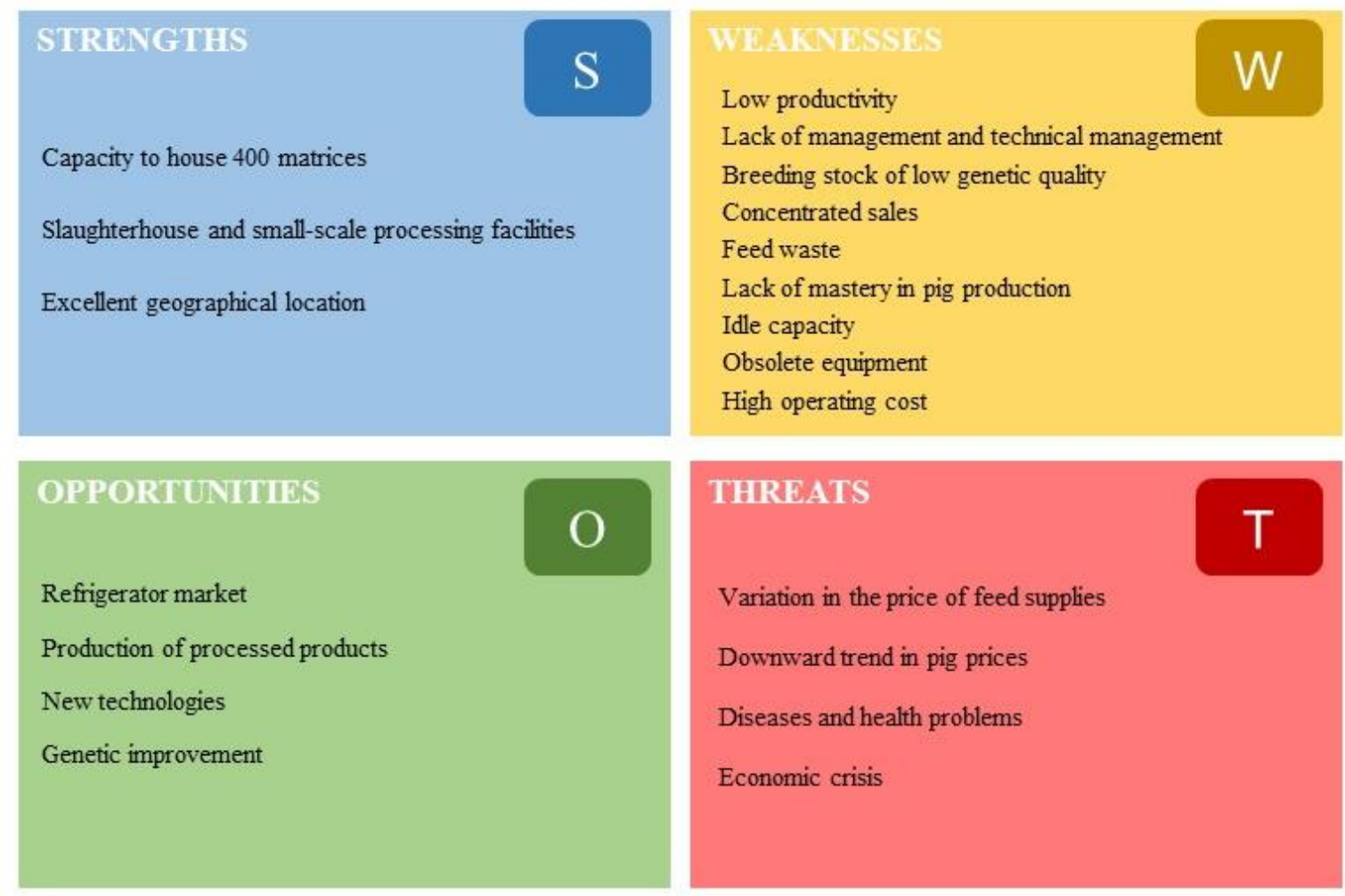

Figure 3. SWOT analysis of the pig operation 


\section{Macrothink}
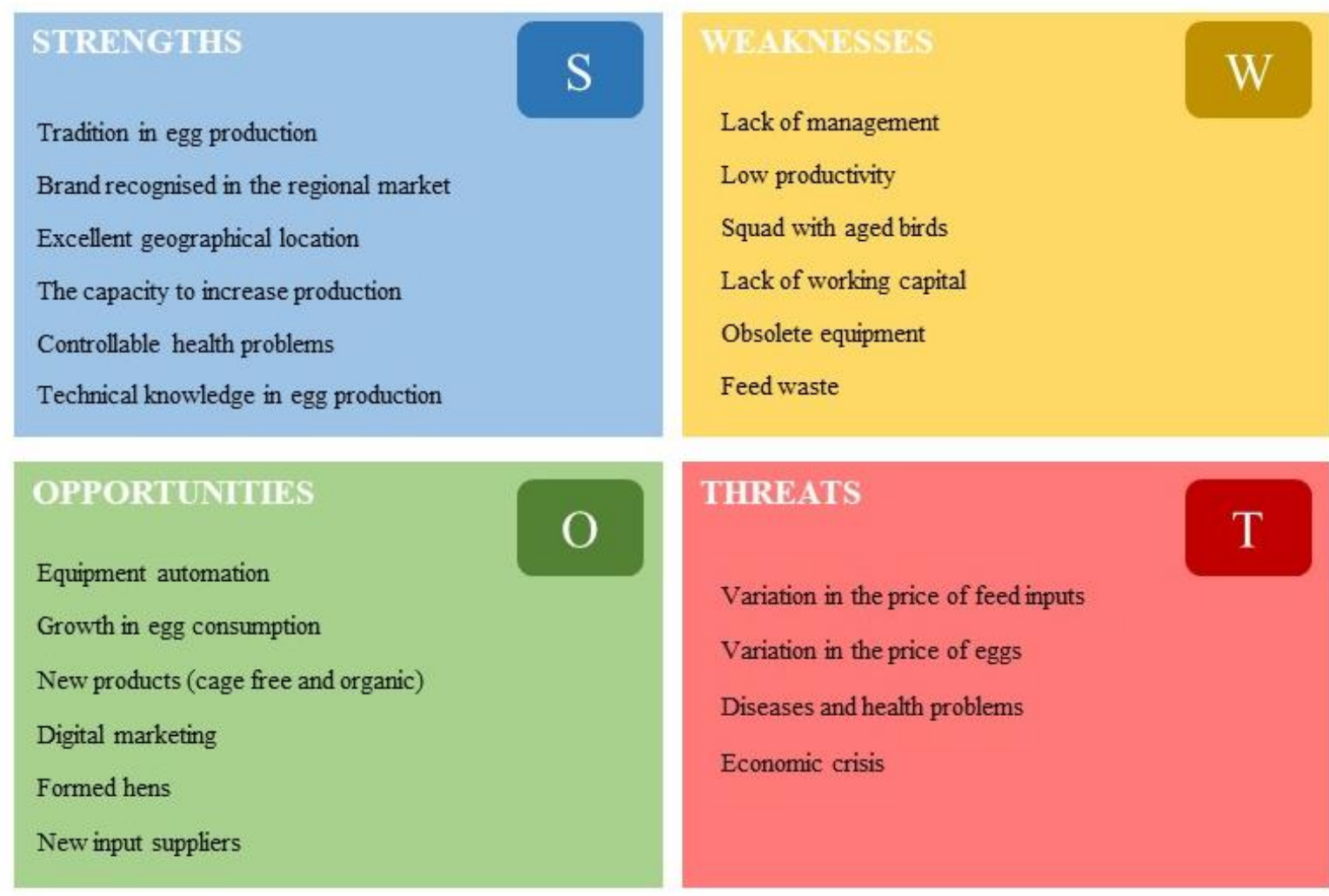

Figure 4. SWOT analysis of the egg operation

By critically analysing the matrices' quadrants, the board identified that the egg operation remained the activity that had developed the most since the company's founding and that focusing on it would reverse the financial results in the short term, as long as the breeding stock was renewed and pig matrices were discarded. The pig operation was an operation that would require a much larger investment to make it efficient and would still have an uncertain return, as it would depend on the performance of technical training in handling. The financial condition of the company would not endure its operation for all this time.

With the results contradicting the directors' view that the pig unit would reverse the company's results, egg production was the most viable solution for the company from a financial point of view. For the owner/manager, making the decision to end the pig operation was exceedingly difficult, as there was a sentimental attachment to the business. For that reason, the decision took six months to be implemented. During this time, the financial crisis worsened even more, and the birds and pigs spent days without food. On the verge of bankruptcy, the directors decided to end the pig production activity and dedicate their management to restructuring the egg farm using the cash flow tool recommended by the researchers.

Due to the absence of a cash flow control already mentioned, it was not possible to calculate the financial indicators from this tool before the model proposed in this research. The financial information reported in this section was collected from the company's historical controls and adapted to the operation of that moment, as well as the amounts updated with the 
prices of inputs, salaries and other costs and expenses in force in the period.

\subsection{After Cash Flow Implementation}

In December 2016, the cash flow tool had its first tests carried out and, after its validation and smooth operation, the tool was implemented in the company in January 2017. This was the first month that the company started selling the pig breeding stock as disposal to small pig slaughterhouses. Due to the difficulty obtaining money, during this period, the researchers controlled the cash flow daily with projected sales and expenses for the next 90 days. To take advantage of the sales during Lent, a seasonal period in which the consumption and price of eggs increase, it was planned to purchase chickens that were already producing and that would enter production with quality eggs. The revenue generated by the sale of part of the discarded breeding stock in January and February paid off the payment for the pullets and the poultry and pork feed was immediately stabilised.

The control of cash flow was no longer being carried out by intuition, and revenues and expenses were reviewed daily with the producer and balanced according to the daily movement of cash flow. Late payments with suppliers were renegotiated and, as a result, some of them started believing in the changes and resumed the credit that had hitherto been suspended. Corn and soy inputs were traded weekly with spot prices and with new suppliers guaranteeing the average price of inputs.

A committee was created, and their members would meet three to four times a week to review next week's cash flow. This committee was attended by the researchers, directors and financial assistant. A new organisational structure was proposed, and the producer's wife became the manager of the commercial area. Every week she received from the researchers a forecast of the need for money for the next week. As most of the egg sales were cash, the dynamics of this forecast worked very well.

Employees' salaries, as well as the thirteenth salary and other benefits, which were overdue, started to be prioritised and at the end of the first quarter they had been paid. The directors started to have fixed salaries per month, and these were calculated according to the couple's household budget plus a variable income according to the calculated result. The couple's personal finances, which were incorporated into the company's finances before using cash flow, became independent.

At the end of the first semester, the average age of the poultry herd had reduced from 120 weeks to 50 weeks and the financial indicators pointed to an improvement in financial performance, as shown in Table III. 
Table III. Financial indicators $-1^{\text {st }}$ Semester of 2017

\begin{tabular}{l|c|c|c|c|c|c|c}
\hline \multicolumn{1}{c|}{ INDICATORS } & JAN & FEB & MAR & APR & MAY & JUN & $\begin{array}{c}\text { TOTAL } \\
\text { S1 }\end{array}$ \\
\hline Are we profitable? & $4.1 \%$ & $2.8 \%$ & $9.4 \%$ & $26.1 \%$ & $20.3 \%$ & $24.3 \%$ & $15.9 \%$ \\
\hline $\begin{array}{l}\text { How much do we use to } \\
\text { reinvest? }\end{array}$ & $21.5 \%$ & $0.0 \%$ & $194.2 \%$ & $0.0 \%$ & $39.2 \%$ & $6.8 \%$ & $33.0 \%$ \\
\hline $\begin{array}{l}\text { How much do we use to pay } \\
\text { debts? }\end{array}$ & $35.4 \%$ & $74.6 \%$ & $-42.6 \%$ & $3.1 \%$ & $46.9 \%$ & $61.1 \%$ & $31.8 \%$ \\
\hline $\begin{array}{l}\text { What is our cash generation } \\
\text { (balance increase) }\end{array}$ & $43.1 \%$ & $25.4 \%$ & $-51.6 \%$ & $96.9 \%$ & $13.9 \%$ & $32.1 \%$ & $35.2 \%$ \\
\hline Minimum cash balance & $-9.4 \%$ & $-9.2 \%$ & $-21.3 \%$ & $64.2 \%$ & $52.7 \%$ & $82.4 \%$ & $95.4 \%$ \\
\hline
\end{tabular}

Profitability in the period was $15.9 \%$, that is, for each $\mathrm{R} \$ 1.00$ of revenue generated, the operation converted $\mathrm{R} \$ 0.16$ as a net result of operating activities. Of this result, $33.0 \%$ was used for improvements in facilities and equipment at the feed factory, warehouse and recreation warehouses. In the face of the renegotiations that occurred during this period, $31.8 \%$ was used to pay debts so that the company could resume supplying part of the main feed inputs and packaging.

Cash generation was $35.2 \%$ in relation to the operating result and the minimum balance required for the operation evolved from negative numbers at the beginning of the period to $95.4 \%$ of the amount required. As the company's focus in the first half was to make the operation viable, the revenues obtained during the period were distributed as $83 \%$ from eggs sales, $14 \%$ from pig disposal sales and 3\% from waste sales (manure, poultry, packaging and others).

The performance of the period had the contribution of several factors, among them the reduction of the prices of feed inputs, such as corn and soybean meal, which corresponded to $60 \%$ to $70 \%$ of the total operation cost. The value of a bag of corn at the end of the first half of 2017 was $\mathrm{R} \$ 25.49$ per bag, compared to $\mathrm{R} \$ 41.28$ in the same period of the previous year, which means that it had had a $61.9 \%$ decrease, according to the Centre of Advanced Studies on Applied Economy (CEPEA, 2019a).

Soybean meal had a reduction of $49.6 \%$ in the price of a metric ton if compared to the same period in 2016 and the price of an egg box with 360 eggs increased $8.1 \%$ when comparing the same periods (CEPEA, 2019b; CEPEA, 2019c). In April 2017, corn consumption was guaranteed by the production of a part of the property's planted area, contributing greatly to cash generation.

The company was able to honour payments of tax liabilities and short-term loans. Purchases of materials and inputs, for the most part, were done with cash payments and very well negotiated to reduce costs. Thus, the cash generated and accumulated in the first semester added R\$ 158083.00 to the company's cash balance. This amount resulted from the sum of cash flows from operating activities, investments and financing.

With positive financial results and the operation resuming its strength with the organisation of finance, from the second semester on, the company started to invest in management, hiring more qualified employees for the administrative, production and commercial sectors. It also 
resumed operations in the poultry breeding sector, which until then were disabled, increasing the breeding stock from 60000 birds to 90000 birds. In addition to this, improvements in the egg production and classification sheds were made, as well as an investment in marketing, by the creation of new labels for packaging, website and brand promotion on social media. A new Enterprise Resource Planning system specialised in laying poultry for production and financial management was acquired. Employee turnover was reduced due to the implementation of a recruitment process, and the organisational structure was reorganised with the creation of an administrative board responsible for strategic planning.

Thus, owing to strict cash flow management, strategic repositioning of the business with a focus on egg production and restructuring of the entire company, the directors managed to make a deal with a supermarket chain. The accumulated result of the company's operating activity, which was on the verge of bankruptcy, was R\$929 605.65 at the end of December 2017.

Table IV. Financial indicators $-2^{\text {nd }}$ Semester of 2017

\begin{tabular}{l|c|c|c|c|c|c|c|c}
\hline \multicolumn{1}{c|}{ INDICATORS } & JUL & AUG & SEP & OCT & NOV & DEC & $\begin{array}{c}\text { TOTAL } \\
\text { S2 }\end{array}$ & $\begin{array}{c}\text { TOTAL } \\
\text { YEAR }\end{array}$ \\
\hline Are we profitable? & $46.1 \%$ & $25.8 \%$ & $13.7 \%$ & $4.5 \%$ & $-4.6 \%$ & $-14.5 \%$ & $15.3 \%$ & $15.6 \%$ \\
\hline $\begin{array}{l}\text { How much do we use to } \\
\text { reinvest? }\end{array}$ & $4.0 \%$ & $17.9 \%$ & $40.1 \%$ & $150.2 \%$ & $-150.1 \%$ & $-46.5 \%$ & $33.1 \%$ & $33.1 \%$ \\
\hline $\begin{array}{l}\text { How much do we use to } \\
\text { pay debts? }\end{array}$ & $46.8 \%$ & $23.0 \%$ & $68.6 \%$ & $94.6 \%$ & $-63.6 \%$ & $-16.0 \%$ & $56.1 \%$ & $44.4 \%$ \\
\hline $\begin{array}{l}\text { What is our cash generation } \\
\text { (balance increase)? }\end{array}$ & $49.3 \%$ & $59.1 \%$ & $-8.8 \%$ & $-144.8 \%$ & $313.7 \%$ & $162.5 \%$ & $10.7 \%$ & $22.5 \%$ \\
\hline \begin{tabular}{l} 
Minimum cash balance \\
\hline
\end{tabular} & $221.5 \%$ & $219.3 \%$ & $241.2 \%$ & $208.7 \%$ & $172.7 \%$ & $108.8 \%$ & $117.0 \%$ & $123.6 \%$ \\
\hline
\end{tabular}

According to Table IV, the amounts committed to investment activities, such as the reforms in the production structure and the replacement of the stock, resulted in a $33.1 \%$ increase in operating activities. Financing activities with interest and debt payments renegotiated with suppliers, banks and third parties added up to $56.1 \%$. Greater dedication to paying liabilities decreased cash generation at the end of the second semester by 24.5 percentage points compared to the first semester.

However, even with the reduction in cash generation, the company managed to overcome the need for the minimum cash balance, remaining $17.0 \%$ above the required limit. Profitability in the second half of the year remained at $15.0 \%$ compared to the first half.

Egg sale prices in the second half decreased due to seasonality and, as of September, revenues decreased by $27 \%$. The selling price of an egg carton at the end of June 2017 was $\mathrm{R} \$ 92.17$ against $\mathrm{R} \$ 72.75$ at the end of December 2017 (CEPEA, 2019b). Not only did sales prices decrease, but corn and soybean meal prices increased from one semester to the next. Corn increased by $32.4 \%$ and soybean meal by $8.5 \%$ (CEPEA, 2019a; CEPEA, 2019c).

Table IV shows that profitability in the months of November and December was negative due to the impact of reduced revenues and increased costs of the main feed inputs. Coming out of 
a financially critical scenario, the company demonstrated, by its indicators, the ability to keep the operation going. Revenues from the sale of piglets and disposal of the pig breeding stock ended in September and accounted for $10.2 \%$ of total revenues generated in the two semesters of 2017.

The researchers' dedication together with the managers in controlling cash flow guaranteed the company an accumulated cash generation at the end of the year of $\mathrm{R} \$ 209591.51$, adding this amount to the final balance of cash and cash equivalents. The variation in the final balance of cash and cash equivalents in relation to the beginning of the period was $951.5 \%$, contributing to the composition of the minimum cash balance, which was $23.6 \%$ above the limit of the minimum cash balance. The company's cash generation could have reached $66.9 \%$ if there were no disbursements for payment of debts and financing, but debt payments decreased the debt balance by $19.6 \%$.

The average terms calculated based on movements in the period are showed in the Table V.

Table V. Calculation of average operating terms

\begin{tabular}{l|c}
\hline \multicolumn{2}{c}{ AVERAGE OPERATING TERMS } \\
\hline Stock of inputs and packaging (in days) & 10 \\
\hline Finished product inventory (in days) & 5 \\
\hline Receipts from customers (in days) & 17 \\
\hline Payments to suppliers (in days) & 21 \\
\hline Cash cycle (in days) & 11 \\
\hline
\end{tabular}

The average terms of storage, customers receipts and suppliers' payments helped the company to form the working capital that until then was zeroed. In addition to adjustments in the deadlines for receiving sales and input payments, the revenue generated from the cessation of the pig farm had relevant participation in the formation of working capital.

\section{Conclusion}

The choice of the cash flow model proposed and adapted by the researchers for use in this work allowed the producer to organise, plan financially and increase business efficiency. From the use of the tool, financial decisions and controls became more organised and planned, avoiding the bankruptcy of the business.

This work is in line with that presented by Afrifa (2016), Ross et al. (2002), and Yahya et al. (2016) as they all state that monitoring cash flow as a management tool helps in financial reorganisation, business survival, financial difficulty avoidance, operational efficiency loss and possible bankruptcy suffering. Strict cash flow control is considered an essential activity to avoid chaos in small and medium-sized business. The absence of cash flow makes it possible for the company to go bankrupt, even if it makes a profit. In Welsh and White's (1981) perspective, the tool is more important than the value of profit or return on investment and being able to honour payments is a matter of life and death for small businesses.

The financial results obtained provided the business not only with financial improvements, but with organisational management through processes, behaviour change and the vision of 
managers. The decision to focus only on the egg production activity resumed the company's expertise that had been built since the business had been founded. The positive results with the egg operation showed that the weaknesses pointed out in the SWOT analysis were assertive for decision-making. However, it must be considered that the intensity, persistence, care and prudence in financial management by the directors could prevent successive financial crises without prospects for recovery. Although the residuals of the crisis periods were not immediately eliminated, the financial restructuring from the cash flow sought to keep the company financially viable with the capacity to continue its operations in order to honour, in the next five years, the renegotiated obligations.

It is important to emphasise that small and medium-sized rural producers - as well as all other entrepreneurs - need to know how to manage the cash generated in order to benefit the company, instead of just using it to increase their standard of living. Personal use or misuse of generated cash can directly affect the expected results. Therefore, the success of a small or medium-sized company is associated with both cash flow management and the skills and behaviour of its owner/manager. Cash flow is not only a tool with a financial statement that can guarantee a company's recovery, it is also a tool that can increase business efficiency.

\section{References}

Afrifa, G. A. (2016). Net working capital, cash flow and performance of UK SMEs. Review of Accounting and Finance, 15(1), 21-44.

Araújo, A. M. P., \& Marion, J. C. (1997). A utilização de modelos decisórios contábeis pelo pequeno e médio produtor rural: um estudo na região de Ribeirão Preto. Universidade de São Paulo.

Assaf Neto, A., \& Silva, C. A. T. (2012). Administração do capital de giro. Atlas.

Bielikova, A., \& Mazanec, J. (2016). Small and medium-sized enterprises in the global economy. International Journal of Scientific \& Engineering Research, 7(10), 364-367.

Centro de Estudos Avançados em Economia Aplicada - CEPEA (2019a). Indicador do milho ESALQ/BM\&FBOVESPA. Departamento de Economia, Administração e Sociologia, Universidade de São Paulo. https://www.cepea.esalq.usp.br/br/indicador/milho.aspx

Centro de Estudos Avançados em Economia Aplicada - CEPEA (2019b), "Consulta - Série histórica" [personal communication]. Message received by ovocepea@usp.br (accessed on 11 February 2019).

Centro de Estudos Avançados em Economia Aplicada - CEPEA (2019c), "Série histórica farelo de soja" [personal communication]. Message received by gracepea@usp.br (accessed on 11 February 2019).

Cheatham, L., \& Cheatham, C. (1993). Utilizing financial statements as cash flow planning and control tools. Managerial Finance, 19(8), 35-49.

Coghlan, D., \& Brannick, T. (2001). Doing action research in your own organization. Sage. 


\section{Macrothink}

Journal of Agricultural Studies

ISSN 2166-0379

2020, Vol. 8, No. 4

Coughlan, P., \& Coghlan, D. (2002). Action research for operations management. International Journal of Operations \& Production Management, 22(2), 220-240.

Das, S. (2017). Analysis of cash flow ratios: a study on CMC. Accounting, 4(1), 41-52.

Deloof, M. (2003). Does working capital management affect profitability of Belgian firms? Journal of Business Finance \& Accounting, 30(4), 573-588.

Financial Accounting Standards Board - FASB (1987). FAS95: Statement of Financial Accounting Standards No.95. Financial Accounting Foundation.

Food and Agriculture Organization of the United Nations - FAO (2016). Value of agricultural production. FAOSTAT. http://www.fao.org/faostat/en/\#data

French, S. (2009). Action research for practising managers. Journal of Management Development, 28(3), 187-204.

Gitman, L. J. (1997). Princípios de administração financeira. Harbra.

Haskins, M. E., Higgs, R. D., \& Ketz, J. E. (1987). Cash flow planning. Planning Review, 15(6), $38-44$.

Instituto Brasileiro de Geografia e Estatística - IBGE (2017a). Demografia das empresas 2015. Estudos e Pesquisas Informação 29. https://biblioteca.ibge.gov.br/visualizacao/livros/liv101151.pdf

Instituto Brasileiro de Geografia e Estatística - IBGE (2017b). Censo Agropecuário 2017: Resultados Preliminares. Ministério do Planejamento, Desenvolvimento e Gestão. https://biblioteca.ibge.gov.br/visualizacao/periodicos/3093/agro_2017_resultados_preliminar es.pdf

Instituto Brasileiro de Geografia e Estatística - IBGE (2018). Produção de ovos de galinha. Sistema IBGE Recuperação Automática (SIDRA) https://sidra.ibge.gov.br/pesquisa/pog/Quadros

Kemmis, S., \& McTaggart, R. (1988). The action research planner. Deakin University Press.

Keynes, J. M. (1982). A teoria geral do emprego, do juro e da moeda. Atlas.

Knight, F. H. (1964). Risk, uncertainty and profit. [PDF file]. Sentry Press. Retrieved from https://cdn.mises.org/Risk,\%20Uncertainty,\%20and\%20Profit_4.pdf

Leone, N. M. C. P. G. (1999). As especificidades das pequenas e médias empresas. Revista de Administração da USP (RAUSP), 34(2), 91-94.

Maingot, M., \& Zeghal, D. (2006). Financial reporting of small business entities in Canada. Journal of Small Business Management, 44(4), 513-530.

Moss, Q. Z., Alho, J., \& Alexander, K. (2007). Performance measurement action research. Journal of Facilities Management, 5(4), 290-300.

Mozzato, A. R., \& Grzybovski, D. (2011). Análise de conteúdo como técnica de análise de 
dados qualitativos no campo da administração: potencial e desafios. Revista de Administração Contemporânea (RAC), 15(4), 731-747.

Opler, T., Pinkowitz, L., Stulz, R. H., \& Williamson, R. (1999). The determinants and implications of corporate cash holdings. Journal of Financial Economics, 52(1), 3-46.

Pais, M. A., \& Gama, P. M. (2015). Working capital management and SMEs profitability: Portuguese evidence. International Journal of Managerial Finance, 11(3), 341-358.

Ross, S. A., Westerfield, R. W., \& Jaffe, J. F. (2002). Administração financeira. Atlas.

Ross, S. A., Westerfield, R. W., \& Jordan, B. D. (1998). Princípios de administração financeira. Atlas.

Serviço Brasileiro de Apoio às Pequenas e Médias Empresas - SEBRAE (2016). Sobrevivência das empresas no Brasil. [PDF file] Retrieved from https://m.sebrae.com.br/Sebrae/Portal\%20Sebrae/Anexos/sobrevivencia-das-empresas-no-bra sil-102016.pdf

Tauringana, V., \& Afrifa, G. A. (2013). The relative importance of working capital management and its components to SMEs' profitability. Journal of Small Business and Enterprise Development, 20(3), 453-469.

Weihrich, H. (1982). The TOWS matrix - a tool for situational analysis. Long Range Planning, 15(2), 54-66.

Welsh, J. A., \& White, J. F. (1981). A small business is not a little big business. Harvard Business Review. Retrieved from https://hbr.org/1981/07/a-small-business-is-not-a-little-big-business

Yahya, F., Ali, S. A., \& Ghazali, Z. (2016). The relevance of agency conflicts in small and medium enterprises. International Journal of Advanced and Applied Sciences, 3(7), 41-45.

\section{Notes}

Note 1. Amounts in Brazilian reais can be converted into US dollars in the proportion of US\$ 1.00 to R\$3.22. Available at: http://ipeadata.gov.br/exibeserie.aspx?serid=38389.

\section{Copyright Disclaimer}

Copyright for this article is retained by the author(s), with first publication rights granted to the journal.

This is an open-access article distributed under the terms and conditions of the Creative Commons Attribution license (http://creativecommons.org/licenses/by/4.0/). 